\title{
Peran Kelompok Sadar Wisata Telok Kombal Dalam Mengembangkan Ekowisata Bukit Sumbur Suma
}

\author{
Muhammad Rahmatul Burhan ${ }^{\text {a1 }}$, Mardiah ${ }^{\text {b2 }}$ \\ aniveritas Muhammadiyah Mataram \\ bUniversitas Muhammadiyah Mataram \\ ${ }^{1}$ ramaehrama@gmail.com , ${ }^{2}$ mardiahmsi226@gmail.com
}

\section{INFO ARTIKEL}

Riwayat Artikel:

Diterima: 07-08-2020

Disetujui: 19-08-2020

\section{Kata Kunci:}

Peran

Pokdarwis

Pariwisata

Ekowisata

Keywords:

Role

Pokdarwis

Tourism

Ecotourism

\begin{abstract}
ABSTRAK
Abstrak: Penelitian ini bertujuan untuk mengetahui peran Pokdarwis dalam pengembangan ekowisata bukit Sumbur Suma di Dusun Telok Kombal Kecamatan Pemenang Kabupaten Lombok Utara. Penelitian ini menggunakan metode studi kasus. Fokus penelitian yaitu mengidentifikasi peran Pokdarwis dengan indikator peran yang dipaparkan oleh Minztberg, yaitu peran antar pribadi, peran yang berhubungan dengan informasi, dan peran pengambil keputusan. Pengumpulan data utama dengan wawancara disandingkan dengan hasil observasi dan dokumentasi. Data dianalisis menggunakan teknik Interactive Model yang melewati dua jenis triangulasi (Triangulasi data dan Triangulasi metodologis). Dalam usahanya mengembangkan ekowisata Bukit Sumbur Suma, Pokdarwis Telok Kombal sudah menjalankan peran sebagaimana mestinya, walaupun masih dihadapkan dengan berbagai kendala. Untuk pengembangan produk, Pokdarwis menjalankan peran pengambil keputusan. Dari segi pengembangan standarisasi, Pokdarwis menjalankan dua peran yaitu peran yang berhubungan dengan informasi dan peran pengambil keputusan. Selanjutnya pemberdayaan masyarakat, Pokdarwis menjalankan dua peran yaitu peran antar pribadi dan peran pengambil keputusan. Kepada stakeholder, Pokdarwis sudah mampu menjalankan keseluruhan perannya.
\end{abstract}

\begin{abstract}
This research aims to determine the role of Pokdarwis in the development of the Sumbur Suma Hill in Telok Kombal, North Lombok. This research uses the case study method. Focus of the research is to examine the role of Pokdarwis with the role indicators presented by Minztberg: Interpersonal roles, Roles related to information, and the role of decision makers. The main data collection by interview was collaborated with the results of observation and documentation. Data were analyzed using an Interactive Model technique that passes through two types of triangulation (data triangulation and methodological triangulation). In an effort to develop the Sumbur Suma Hill ecotourism, Pokdarwis Telok Kombal has performed its role as it should, although it is still faced with various obstacles. For product development, Pokdarwis plays the role of decision maker. In terms of standardization development, Pokdarwis plays two roles, the role associated with information and the role of decision makers. Then community empowerment, Pokdarwis plays two roles, interpersonal role and decision maker role. The stakeholder part, Pokdarwis has been able to carry out its entire role.
\end{abstract}

\section{LATAR BELAKANG}

Ekowisata merupakan salah satu kegiatan parawisata yang berwawasan lingkungan dengan mengutamakan aspek konservasi alam, aspek perberdayaan sosial budaya ekonomi masyarakat lokal serta aspek pembelajaran dan pendidikan. Menurut Damanik dan Weber (2006), ekowisata merupakan kegiatan yang bertanggung jawab terhadap kesejahteraan masyarakat lokal dan pelestarian lingkungan. Sedangkan menurut Fennel (2008) Ekowisata muncul sebagai solusi atas kekhawatiran terhadap wisata konvensional yang cenderung mengejar keuntungan ekonomi dan mengabaikan aspek sosial serta kelestarian lingkungan.

Ekowisata merupakan salah satu bentuk wisata minat khusus yang saat ini tengah berkembang di Indonesia. Salah satunya di Dusun Telok Kombal Kecamatan Pemenang Kabupaten Lombok Utara terdapat sebuah bukit indah yang bisa menjadi destinasi baru bagi pengembangan ekowisata di Kabupaten Lombok Utara. Bukit 
tersebut bernama Bukit Sumbur Suma yang dibuka oleh Kelompok Sadar Wisata (Pokdarwis) Dusun Telok Kombal pada tanggal 17 agustus 2019.

Bukit Sumbur Suma memiliki potensi karena memiliki keunikan dan kemistisan yang diyakini masyarakat setempat, yaitu : (a) Mata air tersebut tidak pernah mengering meskipun musim kemarau, (b) Air tersebut masih dijadikan obat dan ritual ketika anak-anak Dusun Teluk Kombal akan melakukan khitanan, (c) Air tersebut akan berkurang volume airnya apabila pengunjungnya memiliki niat dan melakukan hal yang tidak terpuji di lokasi Sumbur Suma, (d) Volume airnya akan berkurang bahkan mengering apabila yang mengambil airnya wanita yang sedang menstruasi.

Potensi dan daya tarik wisata bukit Sumbur Suma belum mendapat bantuan dari Pemerintah Daerah Kabupaten Lombok Utara untuk pengembangannya. Sejauh ini Kelompok Sadar Wisata (Pokdarwis) Dusun Telok Kombal hanya menggunakan sumber daya dari masyarakat setempat dan anggota Pokdarwis itu sendiri.

Peran Pokdarwis merupakan salah satu hal yang penting dalam pengembangan ekowisata untuk mengeluarkan potensi wisata suatu daerah. Rahim (2012) menyatakan bahwa Kelompok Sadar Wisata (Pokdarwis) merupakan sebuah kelembagaan di tingkat masyarakat yang anggotanya terdiri dari para pelaku kepariwisataan yang memiliki kepedulian dan tanggung jawab serta berperan aktif sebagai penggerak dalam mendukung terciptanya iklim kondusif bagi tumbuh dan berkembangnya kepariwisataan serta terwujudnya septa pesona dalam meningkatkan pembangunan daerah melalui kepariwisataan dan manfaatnya bagi kelestarian alam. Pernyataan tersebut menggambarkan tanggung jawab Pokdarwis salah satunya adalah melestarikan alam di mana sesuai dengan konsep ekowisata yang mengutamakan pelestarian lingkungan.

Beberapa rujukan mengenai bagaimana langkah dan pentingnya Pokdarwis dalam melakukan tugasnya telah diungkapkan dalam penelitian sebelumnya, Haryati, Armawi, Supraja (2016) mengatakan bahwa pemuda Pokdarwis harus aktif melakukan sosialisasi kepada masyarakat dan pemerintah daerah betapa pentingnya pengembangan ekowisata. Kemudian selain sosialisasi, pemuda Pokdarwis juga aktif mengajak pemuda lain untuk mengelola kawasan ekowisata melalui pendekatan emosional.

Selanjutnya penelitian oleh Wijaya, Zulkarnain, Sopingi (2016) menyatakan pengembangan desa wisata berbasis ekowisata harus memiliki atau menyediakan wahana komunikasi antara wisatawan dengan masyarakat lokal untuk berbagi pengalaman dan pengetahuan dalam mewujudkan kehidupan yang ramah lingkungan. Selain itu wahana yang disediakan dapat memancing wisatawan untuk turut serta melestarikan alam sekitar.

Oleh karena itu, tugas Pokdarwis untuk meningkatkan daya tarik yang disediakan oleh destinasi ekowisata sehingga Pokdarwis harus bisa meningkatkan ekonomi masyarakat melalui pengembangan pariwisata baik itu dari destinasinya ataupun produk masyarakat (Hani'ah, 2017). Untuk mencapai itu, Pokdarwis harus memiliki menejemen yang terarah dan melakukan fungsi menejemen yang benar dari planning, organizing, actuating, dan controlling. Selain itu lokasi wisata juga harus didukung dengan prasarana yang ramah lingkungan misalnya pembuatan fasilitas menggunakan bahan dari alam (Anggraeny, 2019).

Berdasarkan paparan di atas, fokus dari penelitian ini yaitu untuk mengetahui peran Pokdarwis di Dusun Telok Kombal dalam mengembangkan ekowisata Bukit Sumbur Suma. Hasil dari penelitian ini agar menjadi tambahan ilmu bagi peneliti dan juga diharapkan mampu menjadi acuan maupun referensi bagi pihak-pihak terkait untuk melakukan perencanaan dalam pengembangan daya tarik ekowisata di masa akan datang.

\section{TINJAUAN PUSTAKA}

Definisi ekowisata yang pertama diperkenalkan oleh organisasi The Ecotourism Society (1990) dalam Bricker (2017), sebagai berikut: Ekowisata adalah suatu bentuk perjalanan wisata ke area alami yang dilakukan dengan tujuan mengkonservasi lingkungan dan 
melestarikan kehidupan dan kesejahteraan penduduk setempat. Semula ekowisata dilakukan oleh wisatawan pecinta alam yang menginginkan di daerah tujuan wisata tetap utuh dan lestari, di samping budaya dan kesejahteraan masyarakatnya tetap terjaga.

Ekowisata merupakan bentuk wisata yang dikelola dengan pendekatan konservasi. Apabila ekowisata pengelolaan alam dan budaya masyarakat yang menjamin kelestarian dan kesejahteraan, sementara konservasi merupakan upaya menjaga kelangsungan pemanfaatan sumberdaya alam untuk waktu kini dan masa mendatang.

Pendekatan lain bahwa ekowisata harus dapat menjamin kelestarian lingkungan. Maksud dari menjamin kelestarian ini seperti halnya tujuan konservasi seperti dikutip dari United Nations Environment Programme (UNEP), sebagai berikut:

a) Menjaga tetap berlangsungnya proses ekologis yang tetap mendukung sistem kehidupan.

b) Melindungi keanekaragaman hayati.

c) Menjamin kelestarian dan pemanfaatan spesies dan ekosistemnya.

Keterpaduan ekonomi dan lingkungan dalam pengem-bangan ekowisata dengan menekankan pada distribusi kembali pendapatan dari ekowisata untuk menciptakan insentif pengendalian dan pengelolaan sumber daya alam kepada masyarakat untuk menjamin perlindungan lingkungan jangka panjang. Meskipun ekowisata tidak selalu menjamin pertumbuhan ekonomi masyarakat dan daerah begitu juga perlindungan lingkungan, kecuali jika dilembagakan secara benar, ekowisata dapat menjadi model pengelolaan sumber daya alam bagi negara-negara berkembang untuk mengha-dapi masa depan (Sama, 2011 dalam Asmin, 2018).

Organisasi atau lembaga paling dekat secara langung yang menjamin kelestarian lingkungan dan keberpihakan kepada masyarakat lokal adalah Kelompok Sadar Wisata (Pokdarwis). Kelompok sadar wisata merupakan kelompok yang tumbuh atas inisiatif dan kemauan serta kesadaran masyarakat sendiri guna ikut berpartisipasi aktif memelihara dan melestarikan berbagai obyek dan daya tarik wisata dalam rangka meningkatkan pembangunan kepariwisataan di daerah. Kelompok sadar wisata sebagai pengelola terselenggaranya desa wisata mampu mengoptimalkan pengembangan desa wisata (Desiati, 2013).

Salah satu aspek mendasar bagi keberhasilan pembangunan kepariwisataan adalah dapat diciptakannya lingkungan dan suasana kondusif yang mendorong tumbuh dan berkembangnya kegiatan kepariwisataan di suatu tempat. Iklim atau lingkungan kondusif tersebut terutama dikaitkan dengan perwujudan Sadar Wisata dan Sapta Pesona yang dikembangkan secara konsisten di kalangan masyarakat yang tinggal di sekitar destinasi pariwisata. Sadar Wisata digambarkan sebagai bentuk kesadaran masyarakat untuk berperan aktif dalam 2 (dua) hal berikut, yaitu: a) Masyarakat menyadari peran dan tanggung jawabnya sebagai tuan rumah (host) yang baik bagi tamu atau wisatawan yang berkunjung untuk mewujudkan lingkungan dan suasana yang kondusif sebagaimana tertuang dalam slogan Sapta Pesona. b) Masyarakat menyadari hak dan kebutuhannya untuk menjadi pelaku wisata atau wisatawan untuk melakukan perjalanan ke suatu daerah tujuan wisata, sebagai wujud kebutuhan dasar untuk berekreasi maupun khususnya dalam mengenal dan mencintai tanah air.

Sapta Pesona adalah 7 (tujuh) unsur pesona yang harus diwujudkan bagi terciptanya lingkungan yang kondusif dan ideal bagi berkembangnya kegiatan kepariwisataan di suatu tempat yang mendorong tumbuhnya minat wisatawan untuk berkunjung".Ketujuh unsur Sapta Pesona yang dimaksud di atas adalah : 1) Aman 2) Tertib 3) Bersih 4) Sejuk 5) Indah 6) Ramah 7) Kenangan (Rahim, 2012).

Dalam hal ini Kelompok Sadar Wisata (Pokdarwis) atau kelompok penggerak pariwisata sebagai bentuk kelembagaan informal yang dibentuk anggota masyarakat (khususnya yang memiliki kepedulian dalam mengembangkan kepariwisataan di daerahnya), merupakan salah satu unsur pemangku kepentingan dalam masyarakat yang memilki keterkaitan dan peran penting dalam mengembangkan dan mewujudkan Sadar Wisata dan Sapta Pesona di daerahnya.

Gambaran posisi dan peran penting Kelompok Sadar Wisata (Pokdarwis) dikaitkan dengan pengembangan kepariwisataan / destinasi pariwisata 
tersebut dalam kerangka kerja yang digunakan dalam penelitian ini.

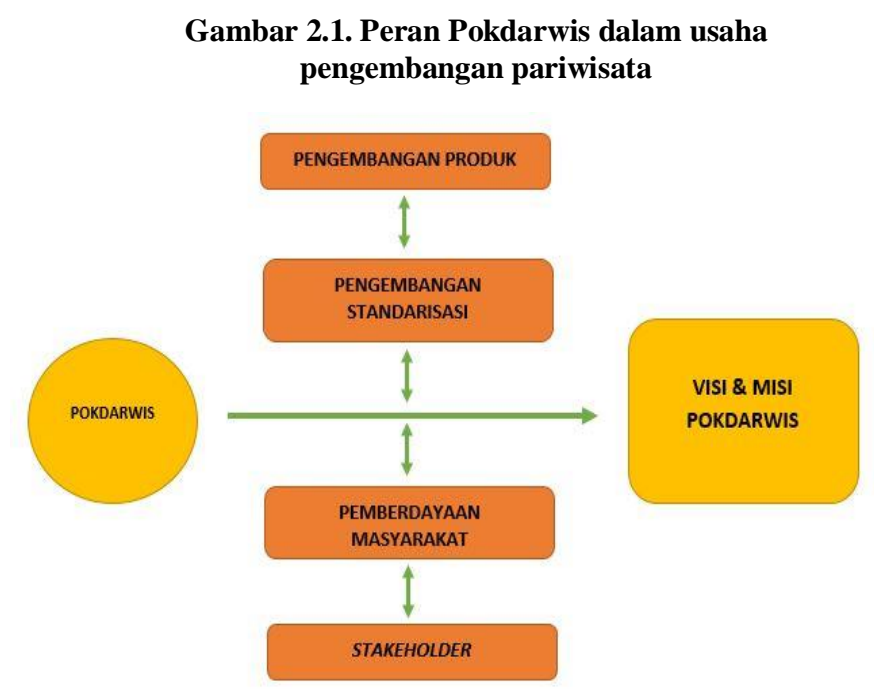

Sumber: Buku Pedoman Kelompok Sadar Wisata (Rahim, 2012).

Rahim (2012) menjelaskan konsep-konsep dalam peran Pokdarwis yang terlihat pada gambar di atas, antara lain:

a. Pengembangan produk: Pengembangan produk yang dimaksud meliputi obyek wisata, fasilitas pendukung, dan pelayanan dari masyarakat.

b. Pengembangan standarisasi yaitu standar kualitas atau mutu yang ditetapkan oleh pokdarwis tersebut maupun daerah.

c. Pemberdayaan masyarakat, bagaimana program sosialisasi dan pelatihan yang diberikan pokdarwis atau pemerintah daerah kepada masyarakat.

d. Stake holder yaitu pihak-pihak yang berkepentingan dalam pengembangan ekowisata.

Untuk menjalankan perannya dalam kegiatan tersebut, Mintzberg dalam Thoha (2012), menyatakan ada tiga peran yang dilakukan dalam organisasi yaitu:

1. Peran Antar Pribadi (Interpersonal Role), dalam peranan antar pribadi, atasan harus bertindak sebagai tokoh, sebagai pemimpin dan sebagai penghubung agar organisasi yang dikelolahnya berjalan dengan lancar.

2. Peranan yang Berhubungan Dengan Informasi (Informational Role), peranan ini terdiri dari peranan-peranan sebagai berikut: a) Peran pemantau (Monitor), peranan ini mengidentifikasikan seorang atasan sebagai penerima dan mengumpulkan informasi.

b) Sebagai diseminator, peranan ini melibatkan atasan untuk menagani proses transmisi dari informasi-informasi kedalam organisasi yang dipimpinnya.

c)Sebagai juru bicara (Spokesman), peranan ini dimainkan manajer untuk menyampaikan informasi keluar lingkungan organisasinya.

3. Peranan Pengambil Keputusan (Decisional Role), dalam peranan ini atasan harus terlibat dalam suatu proses pembuatan strategi di dalam organisasi yang di pimpinnya. Mintzberg berkesimpulan bahwa sebagian besar tugas atasan pada hakikatnya digunakan secara penuh untuk memikirkan sisitem pembuatan strategi organisasinya.

\section{METODE PENELITIAN}

Penelitian ini secara spesifik menggunakan jenis pendekatan studi kasus, seperti pendapat Creswell (1994) dalam Manzilati (2017) yang mengemukakan pada pendekatan studi kasus, peneliti menelusuri suatu aktivitas, proses, atau sekelompok individu secara spesifik. Pendekatan ini bersifat lebih spesifik dibandingkan pendekatan lain dalam metode kualitatif karena peneliti mengambil fenomena spesifik sebagai masalah penelitian, kemudian menetapkan kelompok individu, tempat, waktu, atau proses tertentu secara spesifik yang menjadi fokus penelitian. Dalam penarikan sampel secara purposive, peneliti mewawancarai tiga orang informan kunci, yaitu: (1) Ketua Pokdarwis, (2) Pihak Dinas Kebudayaan dan Pariwisata Kabupaten Lombok Utara, dan (3) Kepala Desa Telok Kombal, Kecamatan Pemenang. Data utama yang didapat dari wawancara, disandingkan dengan data pendukung dari hasil observasi dan dokumentasi. Hasil pengumpulan data dianalisis menggunakan teknik Interactive Model. Kemudian melewati tahap dua jenis metode triangulasi, yaitu triangulasi data dan triangulasi metodologis untuk ditarik kesimpulan.

\section{PEMBAHASAN}

Pokdarwis Dusun Telok Kombal sebagai pengelola destinasi wisata Bukit Sumbur Suma 
sudah berjalan sesuai dengan rencana pengembangan obyek wisata yang sudah ditetapkan yang ingin dicapai sejak awal pembentukannya. Total jumlah anggota aktif yaitu 17 anggota, 80\% anggotanya adalah pelaku wisata baik yang masih aktif dan bekerja di sektor parawisata dan gili (Air, Meno, dan Trawanagan) dan 20\% anggotanya adalah pelajar dan mahasiswa.

Dari awal pembentukannya Pokdarwis terdiri dari remaja-remaja aktif Dusun Telok Kombal yang memiliki keinginan dusun tempat tinggal mereka menjadi destinasi wisata yang banyak dikunjungi wisatawan kemudian dapat meningkatkan kesejahteraan masyarakat untuk memiliki perekonomian yang mandiri bagi masyarakat.

Visi Pokdarwis ini untuk meningkatkan kesejahteraan masyarakat Dusun Telok Kombal melalui parawisata. Dari misinya, pemuda pokdarwis sangat peduli terhadap kesejahteraan masyarakat dan kelestarian alam di dusunnya. Oleh karenanya Pokdarwis berinisiatif untuk mengembangkan Bukit Sumbur Suma menjadi destinasi ekowisata baru yang dapat dimanfaatkan untuk membantu perekonomian masyarakat dengan memanfaatkan keindahan bukit sebagai area camping ground dan soft tracking.

Rencana pengembangan destinasi wisata oleh Pokdarwis sudah ditetapkan, yaitu untuk jangka pendek rencananya adalah menjadikan Bukit Sumbur Suma sebagai destinasi wisata camping ground. Sedangkan rencana jangka panjangnya adalah wisata Bukit Sumbur Suma sebagai tempat sunset hill, soft tracking dan membuka kedai-kedai kecil tepat di sekitaran area camping ground. Langkah itu agar dimanfaatkan oleh wisatawan menikmati indahnya matahari tenggelam dengan menyuguhkan jajanan lokal masyarakat demi menjaga kelestarian makanan tradisional kabupaten Lombok Utara.

Sebagai hasil penelitian yang melihat peran Pokdarwis dalam pengembangan ekowisata telah dianalisis, sebagai berikut:

\section{a. Pengembangan Produk}

Pengembangan produk merupakan salah satu tahap dalam mengembangkan suatu destinasi wisata di mana pengembangan produk ini menunjang untuk membuat suatu destinasi menambah daya tarik obyek wisatanya serta membuat wisatawan menjadi nyaman dan betah bahkan bisa membuat wisatan tertarik untuk lebih lama ataupun ingin kembali untuk menikmati pariwisata di tempat tersebut (Rahim, 2012).

Pengakuan Pokdarwis menggambarkan bahwa wisata Sumbur Suma telah melakukan beberapa pengembangan. Pada destiansi wisata ini pengembangan produk yang dilakukan oleh Pokdarwis yaitu memperbaiki tempat parkir yang layak, penambahan titik foto yang bagus bagi wisatawan, dan penambahan jumlah tenda yang disewakan.

Pengakuan Pokdarwis berbeda dengan pengakuan oleh pihak Dinas Kebudayaan dan Parawisata Kabupaten Lombok Utara, yang menyatakan belum ada pengembangan produk yang dilakukan Pokdarwis. Sejauh ini Pokdarwis hanya melakukan promosi pada destinasi wisatanya saja.

Setelah dikonfirmasi kembali, kurangnya koordinasi antara Pokdarwis dan dinas terkait memang benar adanya. Sebagai Pokdarwis yang bertanggung jawab langsung terhadap destinasi Bukit Sumbur Suma, Pokdarwis menjalankan perannya yaitu peran pengambil keputusan. Pokdarwis sudah menjalankan tugas sebagai organisasi yang bertanggung jawab langsung yaitu membuat perencanaan dan strategi untuk mengembangan produk dan juga mengatur anggotanya dalam memperbaiki tempat parkir yang layak dan aman bagi pengunjung Bukit Sumbur Suma.

\section{b. Pengembangan Standarisasi}

Pengembangan standarisasi merupakan proses penetapan standar yang ingin dicapai dalam waktu yang sudah ditentukan, pengembangan standarisasi dilakukan untuk menetapkan dan membuat perencanaan kerja dari pokdarwis untuk mengembangkan destinasi wisatanya (Rahim, 2012).

Pengembangan standarisasi pemerintah daerah setempat tidak memberikan standar khusus dalam pengembangan wisata Bukit Sumbur Suma. Namun, standar yang ditetapkan secara umum 
destinasi wisata Lombok Utara dikunjungi banyak wisatawan baik wisatawan lokal maupun luar. Pokdarwis memiliki standar sendiri dalam jalannya organisasi, seperti Pokdarwis ingin agar Pokdarwis dijadikan wadah bagi remaja maupun masyarakat beraktifitas yang bermanfaat serta membuat anggotanya memiliki ikatan yang kuat. Sehingga dapat bertukar ilmu atau ide untuk mengembangkan ekowisata Bukit Sumbur Suma.

Pengembangan Standarisasi, Pokdarwis menjalani peran yaitu peran yang berhubungan dengan informasi dan peran pengambil keputusan. Dalam Peran informasi, Pokdarwis sudah mencari informasi tentang standar parawisata Kabupaten Lombok Utara namun memang tidak ada standar yang diberikan oleh pemerintah setempat dalam pengembangan standarisasi. Kemudian peran pengambil keputusan, Pokdarwis harus mengambil keputusan dalam semua yang berkaitan dengan jalannya organisasinya dengan mengambil keputusan membuat standarisasi khusus bagi Pokdarwis Dusun Telok Kombal.

\section{c. Pemberdayaan Masyarakat}

Perberdayaan masyarakat adalah kegiatan pemberian pengetahuan kepada masyarakat baik itu pelatihan kewirausahaan atau pendidikan mengembangkan destinasi wisata yang bisa mendorong ekonomi masyarakat menjadi lebih baik. Kegiatan pemberdayaan masyarakat sangat penting karena kemajuan sutu daerah atau negara harus didukung oleh sumber daya manusia yang memadai dan dapat bersaing dengan sumber daya manusia negara lain (Rahim, 2012).

Kegiatan pemberdayaan masyarakat berupa pelatihan kewirausahaan oleh Pokdarwis Dusun Telok Kombal belum pernah dilakukan, sejauh ini Pokdarwis hanya fokus untuk promosi pada destinasi Bukit Sumbur Suma. Namun, Pokdarwis membentuk Balai Literasi Telok Kombal di mana tugasnya melakukan pendidikan berupa pengetahuan pentingnya peran sumber daya manusia dan melakukan pelatihan kewirausahaan. Keterbatasan tersebut diakibatkan karena kurangnya modal dan tenaga yang dimiliki Pokdarwis. Sedangkan koordinasi dengan pemerintah daerah masih sangat kurang karena
Pokdarwis masih terlalu fokus pada promosi destinasinya saja mengingat destinasi ini masih sangat baru. Peneliti rasa wajar bahwa promosi adalah hal yang paling utama dilakukan oleh Pokdarwis untuk saat ini.

Peran Pokdarwis dalam pemberdayaan masyarakat yaitu peran antar pribadi dan peran mengambil keputusan. Pokdarwis yang masih aktif mempromosikan destinasinya menunjukkan bahwa peran antar pribadi sudah dapat dipenuhi. Sedangkan peran pengambil keputusan, Pokdarwis yang membuat Balai Literasi Telok Kombal sebagai bentuk perencanaan Pokdarwis untuk melakukan pemberdayaan terhadap masyarakat.

\section{d. Stakeholder}

Sebuah pengembangan wisata tentunya tidak akan lepas oleh stakeholder atau pihak pihak yang memiki kepntingan dalam pengembangan wisata tersebut. Stakeholder adalah suatu masyarakat, kelompok, komunitas ataupun individu manusia yang memiliki hubungan dan kepentingan terhadap suatu organisasi atau perusahaan. Stakeholder merupakan faktor pendukung utama jalannya sebuah organisasi begitu juga dengan Pokdarwis (Rahim, 2012).

Stakeholder yang berhubungan dengan pengembangan destinasi Bukit Sumbur Suma kebanyakan tidak jauh dari lingkungan Dusun Telok Kombal yaitu Pokdarwis, Kepala Dusun Telok Kombal, Dinas Kebudayaan dan Pariwisata Kabupaten Lombok Utara, dan pemilik lahan. Karena masih baru, belum ada stakeholder berupa investor yang berpartisipasi dalam pengembangan ekowisata ini.

Pokdarwis sudah menjalankan semua perannya dilihat dari aktif dan Ikut sertanya stakeholder dalam mengembangkan destinasi Bukit Sumbur Suma. Dalam hal ini diharapkan pihak-pihak yang memiliki kepentingan diharapkan terus menunjukkan partisipasinya supaya destinasi ini diminati wisatawan yang berkunjung ke Kabupaten Lombok Utara. Kemudian dapat dilihat pada pihak-pihak yang aktif berbagi informasi dengan orang lain tentang ekowisata Bukit Sumbur Suma, dan terakhir peran 
pengambil keputusan dilihat dari Pokdarwis sudah membuat stakeholder ikut mempromosikan ekowisata Bukit Sumbur Suma.

\section{KESIMPULAN DAN SARAN}

\section{Kesimpulan}

Dalam usahanya mengembangkan ekowisata Bukit Sumbur Suma, peran Pokdarwis Telok Kombal dapat dilihat sebagai berikut:

a. Pengembangan Produk.

Pada bagian ini Pokdarwis menjalankan peran pengambil keputusan dengan bertanggung jawab langsung membuat perencanaan dan strategi untuk mengembangan produk dan juga mengatur anggotanya dalam memperbaiki tempat parkir yang layak dan aman bagi pengunjung Bukit Sumbur Suma. Dua peran lain yaitu peran yang berhubungan dengan informasi dan peran antar pribadi belum dijalankan.

b. Pengembangan Standarisasi.

Pada bagian ini Pokdarwis menjalankan dua peran yaitu peran yang berhubungan dengan informasi dan peran pengambil keputusan dengan membuat anggotanya memiliki ikatan yang kuat. Sehingga dapat bertukar ilmu dan ide untuk mengembangkan ekowisata Bukit Sumbur Suma. Sedangkan ada satu peran yang belum dijalankan yaitu peran antar pribadi.

c. Pemberdayaan Masyarakat.

Untuk pemberdayaan masyarakat, Pokdarwis menjalankan dua peran yaitu peran antar pribadi dan peran pengambil keputusan. Pokdarwis menugaskan anggotanya berbagi pengetahuan kepada masyarakat setempat terkait ide-ide dan rencana pengembangan ekowisata di Bukit Sumbur Suma. Pokdarwis juga membentuk Balai Literasi Telok Kombal, di mana tugasnya melakukan pendidikan berupa pengetahuan pentingnya peran sumber daya manusia dan melakukan pelatihan kewirausahaan. sedangkan satu peran yang belum dijalankan adalah peran yang berhubungan dengan informasi.

\section{d. Stakeholder}

Dalam merangkul stakeholder, Pokdarwis sudah mampu menjalankan ketiga perannya. Terbukti dari semua pihak-pihak yang memiliki kepentingan tersebut sudah aktif ikut mempromosikan destinasi wisata. Diharapkan kedepannya Pokdarwis mampu terus mempertahankan perannya terhadap stakeholder.

Secara keseluruhan Pokdarwis Dusun Telok Kombal sudah menjalankan perannya. Pokdarwis sudah menjalankan fungsinya sebagai lembaga atau organisasi yang memberdayakan masyarakat lokal untuk peduli terhadap destinasi ekowisata yang berorientasi kepada pelestarian lingkungan, walaupun masih ada dimensi peran yang belum dijalankan. Hal itu karena destinasi ekowisata Bukit Sumbur Suma baru dibentuk dan baru dikembangkan.

\section{Saran}

Berdasarkan hasil penelitian, Pokdarwis sudah menjalankan peran sebagaimana mestinya, walaupun masih ada kekurangan-kekurangan yang dihadapi. Untuk itu, saran yang direkomendasikan antara lain:

a. Hendaknya Pokdarwis lebih memperkuat kontak dengan pemerintah daerah supaya dapat lebih mudah meminta bantuan dalam pengembangan ekowisata Bukit Sumbur Suma.

b. Pokdarwis segera melakukan pemberdayaan masyarakat dalam meningkatkan kemampuan sumber daya manusia melalui kegiatan pelatihan, workshop, seminar tentang pengelolaan obyek wisata.

c. Penelitian ini tidak lepas dari keterbatasan, untuk itu penelitian selanjutnya diharapkan mampu mengembangkan penelitian serupa dengan lokasi penelitian yang berbeda dan lebih luas dengan sampling yang lebih banyak guna menambah kualitas data dan hasil penelitian untuk kemajuan pengetahuan ke depan. 


\section{UCAPAN TERIMA KASIH}

Penulis mengucapkan terima kasih kepada pihak-pihak yang membantu jalannya penelitian ini, khususnya Pokdarwis Telok Kombal, Dinas Kebudayaan dan Pariwisata Kabupaten Lombok Utara, istri tercinta dan rekan-rekan sejawat.

\section{DAFTAR RUJUKAN}

\section{Buku}

Asmin, F. (2018). Ekowisata dan Pembangunan Berkelanjutan: Dimulai dari Konsep Sederhana. Bogor: Bogor Agricultural University.

Damanik, J., \& Weber, H. (2006). Perencanaan Ekowisata Dari Teori Ke Aplikasi, Yogyakarta: Pusat Studi Pariwisata (Puspar) UGM dan Andi Press.

Fennell, D. (2008). Ecotourism. New York: Roudledge.

Manzilati, A. (2017). Metode Penelitian Kualitatif: Paradigma, Metode, dan Aplikasi. Malang: Universitas Brawijaya Press (UB Press).

Rahim, F. (2012). Buku Pedoman Kelompok Sadar Wisata. Jakarta: Direktur Jenderal Pengembangan Destinasi Pariwisata Kementerian Pariwisata dan Ekonomi Kreatif.

Thoha, M. (2012). Kepemimpinan dalam Manajemen. Jakarta: Raja Grafindo Persada.

\section{Jurnal}

Anggraeny, Y. M. A. (2019). Peran Kelompok Sadar Wisata (Pokdarwis) Sonokeling Dalam Pengembangan Wisata Basecamp Gunung Tanggamus. (Bachelor Degree), Universitas Lampung., Lampung.

Bricker, K. (2017). Travel and Tourism Research Association: Advancing Tourism Research Globally. The International Ecotourism Society, 11.

Desiati, R. (2013). Pemberdayaan Masyarakat Melalui Pengelolaan Program Desa Wisata. Diklus.

Hani'ah, J. (2017), Peran Pokdarwis Pancoh Dalam Meningkatkan Partisipasi Masyarakat Sebagai Upaya Pengembangan Desa Wisata Pancoh, Turi, Sleman, Jurnal Pendidikan Luar Sekoilah 4(3).

Haryati, S., Armawi, A., \& Supraja, M. (2016). Peran Pemuda Dalam Mengelola Kawasan Ekowisata Dan Implikasinya Terhadap Ketahanan Masyarakat Desa (Studi Tentang Pemuda Pengelola Desa Wisata Kandri, Kecamatan Gunungpati, Kota Semarang, Provinsi Jawa Tengah). Jurnal Ketahanan Nasional, 22.

Wijaya, S.S., Zulkarnain., \& Sopingi. (2016). Proses Belajar Kelompok Sadar Wisata (POKDARWIS) dalam Pengembangan Kampoeng Ekowisata. Jurnal Pendidikan Nonformal, 11(2).

Wood, M. E. (1999). The Ecotourism Society'- An International NGO Commited to Sustainable Development. Tourism Recreation Research, 24 (2).

\section{World Wide Web}

https://www.unenvironment.org/explore-topics/resource-efficiency 